ПРИМЕНА ЕЛЕКТРОНСКОГ ПОСЛОВАЊА

КОД ПРАЋЕЊА ПРОМЕТА И ПОТРОШЊЕ ЛЕКОВА

ЗА ХУМАНУ УПОТРЕБУ У РЕПУБЛИЦИ СРБИЈИ

\author{
Данка Тешић, Татјана Стојадиновић, Јелена Анђелковић
}

Агенција за лекове и медицинска средства Србије

\title{
APPLICATION OF ELECTRONIC BUSINESS \\ IN MONITORING MARKETING AND CONSUMPTION \\ OF HUMAN MEDICINES IN THE REPUBLIC OF SERBIA
}

\section{Danka Tešić, Tatjana Stojadinović, Jelena Anđelković}

\section{Medicines and Medical Devices Agency of Serbia}

Примљен/Received: 16.6.2011.

Прихваћен/Accepted: 14.7.2011.

\section{СКРАЋЕНИЦЕ:}

RUP - Rational Unified Process

UML - Unified Modeling Language

АТЦ - Анатомско терапијско хемијска класификација

ДДД - Дефинисана дневна доза

G2B - Government to business

\section{САЖЕТАК}

У раду је описана примена електронског пословања код праћења промета и потрошње лекова, као једне од „e-government“ услуга Републике Србије. Приказан је методолошки оквир за развој е-услуге, коришћењем "Rational Unified Process" методологије. За опис модела система коришћена је „Unified Modeling Language“ нотација. Приказано је моделирање процеса промета лекова за хуману употребу, као и развој информационог подсистема којим је овај процес подржан. Анализа промета лекова у Србији је спроведена у 2006., 2007., 2008. и 2009. години у Агенцији за лекове и медицинска средства Србије. Подаци су обрађени применом јединствене Анатомско терапијско хемијске класифика- ције лекова и методологијом Дефинисане дневне дозе (ДДД). Обим потрошње лекова се преводи у број ДДД на 1000 становника по дану, који омогућава увид у то колики је број становника (од њих 1000) користио посматрани лек и био изложен његовом деловању током једног дана.

Добијени подаци се стављају у корелацију са бројем становника који су користили лек у периоду за који се врши обрада. У 2006. години остварен је укупан промет лекова за хуману употребу у износу од 510.833.609,54 евра, а у 2007. години остварен је укупан промет лекова од 687.588.174,80 евра, у 2008. години 799.082.221,05 евра док је 2009. износио 741.981.960,19 евра. Обрадом података ДДД методологијом, добијају се следећи подаци: 1013,70 дДД/1000 стан/дан у 2006. години; 2007. године 1084,34 ДДД/1000 стан/дан; 2008. 1219,57 дДД/1000 стан/дан а 2009. 1177,72 ДДД/1000 стан/дан.

Имплементација оваквог система доводи до низа технолошких, функционалних и дугорочних економских предности, као што су: боље управљање документима и записима у државној управи и здравственом систему, отворен, флексибилан, конфигурисан систем и

Контакт: Данка Тешић

Војводе Степе 343 4/4, 11000 Београд

e-mail: danka.tesic@alims.gov.rs, danka_tesic@yahoo.com 
интеграција са другим информационим системима, као и могућност аутоматизације интегрисаних процеса.

Кључне речи: интернет, е-услуга, е-пословање, промет лекова, дневна дефинисана доза

\section{ABSTRACT}

The paper describes the application of electronic business (e-business) in monitoring marketing and consumption of medicines, as one of e-government services (e-services) of the Republic of Serbia (Serbia). It shows methodological framework for development of e-services, through use of RUP (Rational Unified Process) methodology. The Unified Modelling Language (UML) notation was used for description of the system model. The paper presents modeling of the process of marketing of medications for human use, as well as development of the information subsystem underpinning it. The analysis of the marketing of medications in Serbia was carried out in 2006, 2007, 2008 and 2009, by the Medicines and Medical Devices Agency of Serbia, which was authorized to collect and analyze data on the marketing and consumption of medicines and medical devices. Data gathered for a particular time period were analyzed using Anatomical Therapeutic Chemical Classificaion and the Defined Daily Doses methodology. The amount of medicines consumed was translated into the DDD by 1000 individuals per day, and gave an insight into the number of individuals (out of 1000 ) who used the medicine under observation and were under its effect during a single day. The data extracted are correlated with the number of individuals who took the medication during the period under observation. In the year 2006 total marketing of medications for human use amounted to $€ 510.833 .609,54$, in 2007 it stood at $€ 687.588 .174,80$, in 2008 it was $€ 799.082 .221,05$, while the overall marketing of medicines in the year 2009 was $€ 741.981 .960,19$. By processing the data by methodology of DDD, the following results were obtained: 1013,70 DDD/1000 individuals/day in year2006; in year 2007, 1084,34 DDD/1000 individuals/day; in year 2008, 1219,57 DDD/1000 individuals/day and in year 2009, 1177,72 DDD/1000 individuals/day.

The implementation of such system produces a series of technological, functional and economic advantages, such as: improved management of documents and records in state administration and health care system, open, flexible, configured and user-friendly system and the integration with other information systems, as well as the possibility of automatization of integrated processes.

Кључне речи: internet, e-services, e-business, drug consumption, Defined Daily Dose

\section{УВОД}

Електронско пословање (е-пословање) се дефинише и као размена информација помоћу електронских мрежа ради остваривања подршке пословним процесима ${ }^{1}$. У остваривању циљева успешног пословања у фармацији и здравству, е-пословање је од великог значаја у домену управљања подацима ${ }^{2}$. Е-пословање је нови модел пословања, који се заснива на модернијој организацији рада применом савремених информационих технологија (ИТ), коришћењу Интернета у пословању, дигитализацији послова и коришћењу криптографских механизама заштите ${ }^{3}$. Систем е-управе Републике Србије (РС) подразумева јединствен центар, који је одговоран за стратешке одлуке, надзор и управљање операцијама и обухвата три фазе: прихватање потребе за променама, фазу преласка и имплементацију у модел јединственог шалтера. Концепт еуправе РС предвиђа интерактивне електронске услуге прилагођене потребама грађана и привреде ${ }^{4}$.

Е-пословање у регулативи лекова и медицинских средстава је е-услуга у е-управи РС. Промет лекова је један од пословних процеса у регулативи лекова и медицинских средстава. Главни циљ овог рада је да укаже на велики значај е-пословања у побољшању пословног процеса праћења промета и потрошње лекова, као једне од е-услуга Србије а самим тим и рационалније употребе лекова у Србији.

Приликом развоја подсистема е-пословања у регулативи а везано за лекове и медицинска средства, као једне од е-услуга у Србији, примењене су методологија развоја пројекта е-управе, методологија развоја е-услуге и методологија за мерење успешности, а у складу са RUP (Rational Unified Proces) методологијом, која примењује принципе итеративности и инкременталности.

Визија е-пословања Агенције за лекове у оквиру пројекта Е-Управа, предвиђа интерактивне електронске услуге прилагођене потребама грађана, државних органа, привредних субјеката (произвођачи, представништва, уво- 
зници, заступништва лекова и медицинских средстава, здравствене и апотекарске установе).

\section{МЕТОД}

\section{Методолошки оквир за развој е-услуге}

Методологија управљања пројектима еуправе обухвата читав циклус од планирања до имплементације система и у складу је са RUP методологијом. RUP је скуп парцијално уређених корака намењених основном циљу да се ефикасно и у предвиђеним оквирима кориснику испоручи систем који у потпуности задовољава његове потребе.

RUP методологија садржи 4 фазе: иницијализација, елаборација, конструкција и транзиција. Треба напоменути да свака фаза може имати произвољан број итерација ${ }^{5}$.

За представљање модела система, коришћена је UML (Unified Modeling Language) нотација ${ }^{6}$. UML је стандардни језик за моделирање у оквиру RUP методологије ${ }^{6,7}$; састоји се од различитих врста дијаграма којима се описују статичке и динамичке особине система: дијаграм случајева коришћења, дијаграм класа, дијаграм секвенци, дијаграм сарадње, дијаграм стања, дијаграм активности, дијаграм компоненти и дијаграм размештаја ${ }^{8}$.

Методологија развоја е-услуге обухвата иницијалну анализу, израду пословног модела (процесни дијаграм тока и техника Event-driven Process Chain), модела система (use case дијаграм, дијаграми интеракција, дијаграм класа и ЕР дијаграм) и модела технологије (архитектурни дијаграм), имплементацију и увођење.

Приказано је моделирање процеса промета лекова за хуману употребу, као и развој информационог подсистема којим је овај процес подржан. Након периода истраживања у овој области добијен је потпуно функционални прототип, који је у употреби у Агенцији за лекове и медицинска средства Србије (Агенција за лекове). Анализа промета лекова за хуману употребу је спроведена за 2006, 2007, 2008. и 2009. годину.

\section{Промет и потрошња лекова} за хуману употребу у Србији

Подаци који су прикупљени за одређени временски период се обрађују применом јединствене класификације лекова АТЦ (Анатомско терапијско хемијска класификација) и методологијом ДДД (Дефинисана дневна доза). Овакав начин обраде података обезбеђује добијање и приказ финансијскостатистичких и епидемиолошких показатеља употребе лекова у једној средини.

Обим потрошње лекова се преводи у број ДДД на 1000 становника по дану, по методологији утврђеној на међународном нивоу. Дефинисана дневна доза (ДДД) је техничка, статистичка јединица мере употребе лека, чија вредност представља просечну дневну дозу за главну индикацију примене лека код одраслих особа, при чему не зависи од цене, фармацеутског облика, јачине или величине паковања лека и не изражава препоручену или стварно употребљену дозу лека. Број ДДД/1000 становника на дан омогућава увид у то колики је број становника (од њих 1000) користио посматрани лек и био изложен његовом деловању током једног дана. Добијени подаци се стављају у корелацију са бројем становника који су користили лек у периоду за који се врши обрада. Подаци о броју становника се преузимају из званичних докумената Републичког завода за статистику. Вредности ДДД за одређени лек, за сваку годину се узимају из званично објављене публикације АТЦ Индекс са ДДД (Norwegian Instute of Public Health) ${ }^{9}$.

Број ДДД/1000 становника/дан се израчунава према формули:

количина продатих л екова у то ку 1 год (mg)

ДДД (mg) х дани х број станов.

х 1000 станов. = ДДД/1000 станов./дан

Промет лекова се приказује у динарима, а израчунава се множењем броја кутија лека у промету са одобреном велепродајном ценом лека. Цене лекова који се налазе на тржишту Србије су под контролом државе, а уређује их ближе Уредба о критеријумима за формирање цена лекова ("Сл. гласник Србије", бр. $117 / 2004,9 / 2005,7 / 2005$ и 111/2005 и 37/08).

Обрадом података о потрошњи готових лекова ДДД методологијом према АТЦ класификацији, добијају се подаци који дају слику фармакотерапијске праксе у једној средини и упоредиви су са подацима других средина које користе исту методологију праћења. Ово је могуће јер је ДДД статистичка мерна јединица, независна од величине паковања, дозе, заштићеног имена лека и произвођача. 
Моделирање процеса промет хуманих лекова

Као први корак развоја пословања имплементиране су прве Web апликације, као део подсистема информационог система, које су развијене кроз следеће фазе: планирање, спецификација захтева, приказ случајева коришћења, анализа и пројектовање, имплементација и анализа резултата. Изабрана је технологија: програмски језик ПХП, оперативни систем Linux, Web сервер Apache, база података My SQL.

Апликација Промет хуманих лекова примењује савремену форму пословања G2B. Наведена апликација омогућава преглед, унос и измену података о регистрованим лековима, унос ДДД вредности за сваки лек, аутоматско прерачунавање ДДД/1000 становника/дан као и унос података о промету лека.

Апстракција "Лек" треба да садржи:

1) назив лека, класификациону и идентификациону шифру ("АТЦ" и ЕАН-код), облик, јачину и паковање лека;

2) интернационални незаштићени назив лека, генеричко име или хемијску формулу активног састојка;

3) назив и адресу произвођача;

4) количину лека;

5) број решења којим је издата дозвола за стављање лека у промет, односно број решења којим је издата дозвола за његов увоз ради истраживања и лечења и

6) назив правног лица за које се врши увоз.

У апликацији је омогућен и преглед, унос, измена и брисање података о корисницима услуга Агенције за лекове, као и о контакт особама корисника услуга (контакт особе за стављање лека у промет или контакт особе за праћење промета лекова или контакт особе за пријаву нежељених реакција на лек).

Носиоци дозвола за лекове приступају овом делу информационог подсистема, преко сајта АЛИМС путем корисничког имена и лозинке, и уносе податке. Након логовања, врши се избор произвођача лекова, чији се промет уноси, затим се проверавају подаци о сваком дефинисаном леку. Уколико су пода- ци у реду, уноси се количина продатог лека, тј. лека у промету за претходну годину. У случају да контакт особа сматра да лек није на најбољи начин дефинисан, уноси напомену са предлогом његове измене. У Агенцији за лекове се разматра напомена и прихвата или одбија, уколико није адекватна. Уколико на списку нема неког лека, а постоје подаци о његовој продаји, онда контакт особа за промет лекова даје предлог дефинисања лека и уноси његов промет. У Агенцији за лекове се врши провера података о леку и лек се уписује у базу података и појављује се на списку лекова одређеног произвођача.

Апликација аутоматски обрађује податке према унапред задатим критеријумима. Омогућено је да се у сваком тренутку добију следећи извештаји: промет лекова према финансијском учешћу према АТЦ групама и ИННy, промет лекова према финансијском учешћу према називу лека, финансијско учешће произвођача у укупном промету, потрошња лекова према ДДД/1000 становника/дан према АТЦ групама и ИНН-у.

Резултати анализе промета лекова у Србији применом е-пословања током 2006, 2007, 2008. и 2009. године

Коришћењем е-пословања код праћења промета лекова током четири године дошло се до следећих резултата:

У 2006. години остварен је укупан промет лекова за хуману употребу у износу од 510.833.609,54 евра, а у 2007. години остварен је укупан промет лекова од 687.588.174,80 евра, у 2008. години 799.082.221,05 евра док је 2009. износио 741.981.960,19 евра. (табела $1)^{10,11,12,13}$.

Даљом обрадом података добијена је још детаљнија анализа учешћа АТЦ група у укупном промету лекова у Србији. Јасно се види у табели 2. да су се у Србији током све четири године, највећа средства издвајала за лекове за лечење болести кардиоваскуларног система (група Ц). Учешће лекова из групе Ц у укупном промету лекова је током све четири године на првом месту и износи око $23 \%$ од укупног промета лекова ${ }^{10,11,12,13}$. 
Табела 1. Укупан промет лекова у 2006, 2007, 2008. и 2009. години у Србији

\begin{tabular}{|l|l|l||}
\hline Година & Динар & Евро \\
\hline \hline 2009 & $71.200 .588 .899,80$ & $741.981 .960,19$ \\
\hline 2008 & $65.972 .228 .169,70$ & $799.082 .221,05$ \\
\hline 2007 & $54.690 .625 .906,61$ & $687.588 .174,80$ \\
\hline 2006 & $42.389 .483 .753,40$ & $510.833 .609,54$ \\
\hline
\end{tabular}

Табела 2. Остварени промет по АТЦ групама у еврима за 2006, 2007, 2008. и 2009. годину

\begin{tabular}{|c|c|c|c|c|c|}
\hline АТЦ група & Назив групе & 2006. & 2007. & 2008. & 2009. \\
\hline $\mathrm{C}$ & $\begin{array}{l}\text { Кардиоваскуларни } \\
\text { систем }\end{array}$ & 122295930,1 & 158399085,9 & 204429126.09 & 161297625,34 \\
\hline $\mathrm{J}$ & $\begin{array}{l}\text { Антиинфективни } \\
\text { лекови за системску } \\
\text { примену }\end{array}$ & 93319443,34 & 117067753,1 & 120658131,61 & 118158836,78 \\
\hline $\mathrm{N}$ & Нервни систем & 58497506,16 & 82961630,26 & 91121741,59 & 87192234,09 \\
\hline A & $\begin{array}{l}\text { Алиментарни тракт } \\
\text { и метаболизам }\end{array}$ & 58420537,69 & 73518781,48 & 95803774,96 & 78161327,46 \\
\hline B & $\begin{array}{l}\text { Крв и крвотворни } \\
\text { органи }\end{array}$ & 42017472,23 & 65662945,3 & 70831798,18 & 74548071,88 \\
\hline $\mathrm{L}$ & $\begin{array}{l}\text { Антинеопластици и } \\
\text { имуномодулатори }\end{array}$ & 30880850,76 & 49424984,02 & 61165810,48 & 68839374,51 \\
\hline M & $\begin{array}{l}\text { Мишићно-костни } \\
\text { систем }\end{array}$ & 30704048,78 & 41554536,72 & 41583387,72 & 35053656,49 \\
\hline $\mathrm{R}$ & $\begin{array}{l}\text { Респираторни } \\
\text { систем }\end{array}$ & 28775481,14 & 32647927,64 & 37534696,165 & 43157947,85 \\
\hline G & $\begin{array}{l}\text { Генитоуринарни } \\
\text { систем и полни } \\
\text { хормони }\end{array}$ & 14331649,8 & 28377567,22 & 26663617,57 & 22461869,31 \\
\hline $\mathrm{H}$ & $\begin{array}{l}\text { Хормонски препа- } \\
\text { рати за системску } \\
\text { примену, искључу- } \\
\text { јући полне хормоне } \\
\text { и инсулине }\end{array}$ & 11275386,08 & 11028781,97 & 12663107,862 & 14184508,73 \\
\hline $\mathrm{D}$ & $\begin{array}{l}\text { Кожа и поткожно } \\
\text { ткиво }\end{array}$ & 7883326,22 & 10607667,46 & 13429550,33 & 10741426,30 \\
\hline$S$ & Сензорни органи & 6391538,38 & 8507489,98 & 11424139,94 & 12951600,15 \\
\hline V & Остало & 5327885,84 & 7093563,32 & 11105517,91 & 14858585,85 \\
\hline$P$ & $\begin{array}{l}\text { Антипаразитни } \\
\text { производи, инсек- } \\
\text { тициди и средства } \\
\text { за заштиту од } \\
\text { инсеката }\end{array}$ & 718709,13 & 735460,42 & 667820,64 & 374895,43 \\
\hline \multicolumn{2}{|l|}{ Укупно } & 510839765,6 & 687588174,8 & 799082221,05 & 741981960,19 \\
\hline
\end{tabular}

Приказ потрошње лекова према броју ДДД на 1000 становника по дану

Према обрачунатим подацима уочава се да је на 1000 становника, у току све четири године, просечно сваког дана, сваки од становника узимао најмање 1 ДДД неког лека. Тачније, 1013,70 ДД/1000 стан/дан 2006. године; 2007. године 1084,34 ДД乙/1000 стан/дан; 
2008. 1219,57 ДДД/1000 стан/дан а 2009. 1177,72 ДДД/1000 стан/дан. Током све четири године на првом месту према учешћу у потрошњи заузимали су лекови из групе Ц.
Потрошња лекова из ове групе је стално расла од 387,81 ДДД/1000 стан/дан 2006. до 414,67 ДДД/1000 стан/дан 2009. године (Табела $3)^{10,11,12,13}$.

Табела 3. Приказ потрошње лекова и примена ДДД на 1000 становника по дану и процентуалном учешћу у 2006, 2007, 2008. и 2009. години

\begin{tabular}{|c|c|c|c|c|c|c|c|c|c|}
\hline & & \multicolumn{2}{|c|}{2006} & \multicolumn{2}{|c|}{2007} & \multicolumn{2}{|c|}{2008} & \multicolumn{2}{|c|}{2009} \\
\hline $\begin{array}{c}\text { АТЦ } \\
\text { група }\end{array}$ & Назив групе & $\begin{array}{c}\text { ДДД/1000 } \\
\text { станов- } \\
\text { ника/дан } \\
\end{array}$ & $\%$ & $\begin{array}{c}\text { ДДД/1000 } \\
\text { станов- } \\
\text { ника/дан } \\
\end{array}$ & $\%$ & $\begin{array}{c}\text { ДДД/1000 } \\
\text { станов- } \\
\text { ника/дан } \\
\end{array}$ & $\%$ & $\begin{array}{c}\text { ДДД/1000 } \\
\text { станов- } \\
\text { ника/дан }\end{array}$ & $\%$ \\
\hline $\mathrm{C}$ & $\begin{array}{l}\text { Кардиоваскуларни } \\
\text { систем }\end{array}$ & 387,81 & 38,26 & 400,06 & 36,89 & 481,69 & 39,50 & 4414,67 & 35,21 \\
\hline $\mathrm{J}$ & $\begin{array}{l}\text { Антиинфективни } \\
\text { лекови за систем- } \\
\text { ску примену }\end{array}$ & 151,14 & 14,91 & 165,61 & 1,27 & 47,39 & 3,886 & 37,98 & 3,23 \\
\hline $\mathrm{N}$ & Нервни систем & 140,58 & 13,87 & 158,21 & 14,59 & 175,11 & 14,36 & 172,26 & 14,63 \\
\hline A & $\begin{array}{l}\text { Алиментарни } \\
\text { тракт и мета- } \\
\text { болизам } \\
\end{array}$ & 115,71 & 11,41 & 121,06 & 11,16 & 133,28 & 10,928 & 114,38 & 9,72 \\
\hline B & $\begin{array}{l}\text { Крв и крвотворни } \\
\text { органи }\end{array}$ & 77,24 & 7,62 & 83,42 & 7,69 & 181,81 & 14,91 & 257,41 & 21,86 \\
\hline $\mathrm{L}$ & $\begin{array}{l}\text { Антинеопластици } \\
\text { и имуномо- } \\
\text { дулатори } \\
\end{array}$ & 61,91 & 6,11 & 58,27 & 5,37 & 2,31 & 0,190 & 2,71 & 0,23 \\
\hline M & $\begin{array}{l}\text { Мишићно-костни } \\
\text { систем }\end{array}$ & 34,21 & 3,37 & 46,50 & 4,29 & 84,26 & 6,909 & 75,53 & 6,41 \\
\hline $\mathrm{R}$ & $\begin{array}{l}\text { Респираторни } \\
\text { систем }\end{array}$ & 17,79 & 1,75 & 19,80 & 1,83 & 69,99 & 5,739 & 48,81 & 4,14 \\
\hline G & $\begin{array}{l}\text { Генитоуринарни } \\
\text { систем и полни } \\
\text { хормони } \\
\end{array}$ & 16,8 & 1,61 & 19,06 & 1,76 & 16,98 & 1,392 & 22,93 & 1,95 \\
\hline $\mathrm{H}$ & $\begin{array}{l}\text { Хормонски пре- } \\
\text { парати за систем- } \\
\text { ску примену, } \\
\text { искључујући } \\
\text { полне хормоне и } \\
\text { инсулине }\end{array}$ & 8,25 & 0,81 & 9,52 & 0,88 & 16,06 & 1,317 & 21,91 & 1,86 \\
\hline $\mathrm{D}$ & $\begin{array}{l}\text { Кожа и поткожно } \\
\text { ткиво }\end{array}$ & 2,12 & 0,21 & 2,32 & 0,21 & 0,07 & 0,006 & 0,12 & 0,01 \\
\hline $\mathrm{S}$ & Сензорни органи & 0,58 & 0,06 & 0,56 & 0,05 & 9,94 & 0,815 & 8,59 & 0,73 \\
\hline $\mathrm{V}$ & Остало & 0,07 & 0,01 & 0,07 & 0,01 & 0,02 & 0,001 & 0,03 & 0,003 \\
\hline $\mathrm{P}$ & $\begin{array}{l}\text { Антипаразитни } \\
\text { производи, инсек- } \\
\text { тициди и средства } \\
\text { за заштиту од } \\
\text { инсеката }\end{array}$ & 0,02 & 0,00 & 0,03 & 0,00 & 0,65 & 0,053 & 0,38 & 0,03 \\
\hline & Укупно & 1013,70 & 100 & 1084,49 & 100 & 1219,57 & 100 & 1177,72 & 100 \\
\hline
\end{tabular}

\section{ДИСКУСИЈА}

Предност методологије ДДД је та што је омогућено поређење потрошње лекова у различитим срединама. Будући да се у Норвешкој као и у Србији подаци прикупљају и обрађују истом методологијом, и да су као и у Србији, резултати праћења потрошње лекова доступни широкој јавности, као поредбена средина изабрана је Норвешка. С обзиром на то да је, према подацима Светске здравствене организације из 2008. године, Норвешка један од земаља са најмањом стопом смртности од кардиоваскуларних болести у Европи, док је
Србија у групи са највећом стопом смртности ${ }^{14}$, извршено је поређење потрошње лекова за лечење кардиоваскуларних болести у ове две средине. Потрошња лекова који се употребљавају за лечење кардиоваскуларних болести (група С) је током све четири године, била већа у Републици Србији него у Норвешкој (Табела 4.).

У оквиру групе "С" највеће учешће у потрошњи, у обе испитиване средине су имали лекови из подгрупе С09 (лекови који делују на ренин-ангиотензин систем) и то, у Србији: 2006. године 168,84 ДДД/1000 становни- 
ка/дан; 2007. године 167,20 дДД/1000 становника/дан; 2008. године чак 219,18 дДД/ 1000 становника/дан а 2009. године 169,53 дДД/1000 становника/дан, док је у Норвешкој потрошња лекова из ове подгрупе током четири испитиване године уједначена и мања него у Србији: 122,$34 ; 117,91 ; 124,64$ и 128,72 ДДД/1000 становника/дан током 2006., 2007., 2008. и 2009. године (Табела 4).

Детаљнијом анализом потрошње лекова, види се да је у оквиру групе „С“ највећа потрошња остварена код лекова из групе С09A инхибитори ангиотензин конвертујућег ензима (АЦЕ), монокомпонентни и то 168,63 ДДД/1000 становника/дан 2006, 166,22 дДД/ 1000 становника/дан 2007. године, 216,89 ДДД/1000 становника/дан 2008. и 164,46
ДДД/1000 становника/дан 2009. године, док је у Норвешкој потрошено 43,40 ДДД/1000 становника/дан 2006; 43,92 ДДД/1000 становника/дан 2007; 44,75 ДДД/1000 становника/ дан 2008. и 45,02 дДД/1000 становника/дан 2009. године. Са друге стране, поредећи потрошњу лекова из групе С10 (лекови који смањују ниво холестерола и триглицерида) у Србији и Норвешкој, уочава се значајна разлика у потрошњи лекова из ове групе. У 2006. године потрошња лекова из групе С10 била је скоро 7 пута већа у Норвешкој него у Србији, у 2007. години скоро 5 пута већа, док је у 2008. и 2009. години потрошња ових лекова била 4 пута већа у Норвешкој него у Србији (Табела 4).

Табела 4. Упоредни приказ потрошње лекова из подгрупа Ц према дДД/1000 становника/дан у 2006, 2007, 2008. и 2009. години у Србији и Норвешкој

\begin{tabular}{|c|c|c|c|c|c|}
\hline \multicolumn{2}{|c|}{ АТЦ група (тећи ниво) } & \multirow{2}{*}{$\begin{array}{c}\text { ДДД/1000 } \\
\text { становника/дан } \\
2006 \\
\text { Србија } \\
\text { Норвешка }\end{array}$} & \multirow{2}{*}{$\begin{array}{c}\text { ДДД/1000 } \\
\text { становника/дан } \\
2007 \\
\text { Србија } \\
\text { Норвешка }\end{array}$} & \multirow{2}{*}{$\begin{array}{c}\text { ДДД/1000 } \\
\text { становника/дан } \\
2008 \\
\text { Србија } \\
\text { Норвешка }\end{array}$} & \multirow{2}{*}{$\begin{array}{c}\text { ДДД/1000 } \\
\text { становника/дан } \\
2009 \\
\text { Србија } \\
\text { Норвешка }\end{array}$} \\
\hline & & & & & \\
\hline $\mathrm{C} 01$ & ТЕРАПИЈА БОЛЕСТИ & $\begin{array}{l}58,07 \\
18,67\end{array}$ & $\begin{array}{l}73,41 \\
17,44\end{array}$ & $\begin{array}{l}63,99 \\
1641\end{array}$ & $\begin{array}{l}55,65 \\
14,92\end{array}$ \\
\hline C01A & срчани гликозиди & $\begin{array}{l}11,09 \\
3,87\end{array}$ & $\begin{array}{l}9,48 \\
3,55\end{array}$ & $\begin{array}{l}8,94 \\
3,11\end{array}$ & $\begin{array}{l}10,20 \\
2.55\end{array}$ \\
\hline $\mathrm{C} 01 \mathrm{~B}$ & $\begin{array}{l}\text { антиаритмици, групе } \\
\text { I и III }\end{array}$ & $\begin{array}{l}8,00 \\
1,46\end{array}$ & $\begin{array}{c}13,75 \\
1,53 \\
\end{array}$ & $\begin{array}{c}10,98 \\
1,64\end{array}$ & $\begin{array}{l}8,90 \\
1,66\end{array}$ \\
\hline $\mathrm{C} 01 \mathrm{C}$ & $\begin{array}{l}\text { стимуланси срчаног } \\
\text { рада, искључујући } \\
\text { срчане гликозиде }\end{array}$ & $\begin{array}{l}0,23 \\
0,28\end{array}$ & $\begin{array}{c}0,161 \\
0,29\end{array}$ & $\begin{array}{l}0,31 \\
0,30\end{array}$ & $\begin{array}{l}0,13 \\
0,33\end{array}$ \\
\hline C01D & $\begin{array}{l}\text { вазодилататори у } \\
\text { терапији болести срца }\end{array}$ & $\begin{array}{l}38,75 \\
13,06\end{array}$ & $\begin{array}{l}50,02 \\
12,07\end{array}$ & $\begin{array}{l}42,76 \\
11,36\end{array}$ & $\begin{array}{l}36,42 \\
10,38\end{array}$ \\
\hline $\mathrm{C} 01 \mathrm{E}$ & $\begin{array}{l}\text { остали лекови у } \\
\text { терапији болести срца }\end{array}$ & $\begin{array}{l}0 \\
0\end{array}$ & $\begin{array}{c}0,001 \\
0\end{array}$ & $\begin{array}{c}0,001 \\
0\end{array}$ & $\begin{array}{c}0,001 \\
0\end{array}$ \\
\hline $\mathrm{C} 02$ & АНТИХИПЕРТЕНЗИВИ & $\begin{array}{l}2,66 \\
4,53\end{array}$ & $\begin{array}{l}2,90 \\
4,41\end{array}$ & $\begin{array}{l}2,65 \\
4,30\end{array}$ & $\begin{array}{l}2,03 \\
4,33\end{array}$ \\
\hline $\mathrm{C} 02 \mathrm{~A}$ & $\begin{array}{l}\text { антиадренергици, } \\
\text { централног деловања }\end{array}$ & $\begin{array}{l}0,99 \\
1,23\end{array}$ & $\begin{array}{l}0,99 \\
1,38\end{array}$ & $\begin{array}{l}0,35 \\
1,34 \\
\end{array}$ & $\begin{array}{l}0,77 \\
1,29 \\
\end{array}$ \\
\hline $\mathrm{C} 02 \mathrm{C}$ & $\begin{array}{l}\text { антиадренергици с } \\
\text { периферним деловањем }\end{array}$ & $\begin{array}{l}1,67 \\
3,30\end{array}$ & $\begin{array}{l}1,912 \\
3,03\end{array}$ & $\begin{array}{l}2,30 \\
2,96\end{array}$ & $\begin{array}{l}1,26 \\
3,04\end{array}$ \\
\hline $\mathrm{C} 03$ & ДИУРЕТИЦИ & $\begin{array}{l}24,26 \\
50,24\end{array}$ & $\begin{array}{l}22,59 \\
51,35\end{array}$ & $\begin{array}{l}31,45 \\
53,14\end{array}$ & $\begin{array}{l}21,96 \\
52,79 \\
\end{array}$ \\
\hline C03A & $\begin{array}{l}\text { слаби диуретици, } \\
\text { тиазиди }\end{array}$ & $\begin{array}{c}3,68 \\
11,45\end{array}$ & $\begin{array}{c}4,83 \\
13,34\end{array}$ & $\begin{array}{c}5,03 \\
15,38\end{array}$ & $\begin{array}{c}4,33 \\
16,15\end{array}$ \\
\hline $\mathrm{C} 03 \mathrm{~B}$ & $\begin{array}{l}\text { слаби диуретици, } \\
\text { искључујући тиазиде }\end{array}$ & $\begin{array}{c}5,06 \\
0\end{array}$ & $\begin{array}{c}5,50 \\
0\end{array}$ & $\begin{array}{c}8,37 \\
0\end{array}$ & $\begin{array}{c}5,34 \\
0\end{array}$ \\
\hline $\mathrm{C} 03 \mathrm{C}$ & $\begin{array}{l}\text { снажни диуретици } \\
\text { (Хенлеове петље) }\end{array}$ & $\begin{array}{l}12,38 \\
30,33 \\
\end{array}$ & $\begin{array}{c}8,42 \\
29,87\end{array}$ & $\begin{array}{l}14,23 \\
29,29 \\
\end{array}$ & $\begin{array}{c}8,22 \\
28,74 \\
\end{array}$ \\
\hline C03D & $\begin{array}{l}\text { диуретици који } \\
\text { штеде калијум }\end{array}$ & $\begin{array}{l}3,14 \\
1,62 \\
\end{array}$ & $\begin{array}{l}3,84 \\
1,63 \\
\end{array}$ & $\begin{array}{l}3,82 \\
1,66 \\
\end{array}$ & $\begin{array}{l}4,07 \\
1,63 \\
\end{array}$ \\
\hline C03E & $\begin{array}{l}\text { комбинације диуретика } \\
\text { који штеде калијум са } \\
\text { осталим диуретицима }\end{array}$ & $\begin{array}{c}0 \\
6,84\end{array}$ & $\begin{array}{c}0 \\
6,51\end{array}$ & $\begin{array}{c}0 \\
6,81\end{array}$ & $\begin{array}{c}0 \\
6,27\end{array}$ \\
\hline
\end{tabular}




\begin{tabular}{|c|c|c|c|c|c|}
\hline $\mathrm{C} 04$ & $\begin{array}{l}\text { ПЕРИФЕРНИ ВАЗО- } \\
\text { ДИЛАТАТОРИ }\end{array}$ & $\begin{array}{c}20,87 \\
0,27\end{array}$ & $\begin{array}{c}22,04 \\
0,24\end{array}$ & $\begin{array}{c}25,14 \\
0,21\end{array}$ & $\begin{array}{c}11,23 \\
0,18\end{array}$ \\
\hline C04A & $\begin{array}{l}\text { периферни } \\
\text { вазодилататори }\end{array}$ & $\begin{array}{c}20,87 \\
0,27\end{array}$ & $\begin{array}{c}22,04 \\
0,24\end{array}$ & $\begin{array}{c}25,14 \\
0,21\end{array}$ & $\begin{array}{c}11,23 \\
0,18\end{array}$ \\
\hline $\mathrm{C} 07$ & $\begin{array}{l}\text { БЛОКАТОРИ БЕТА } \\
\text { АДРЕНЕРГИЧКИХ } \\
\text { РЕЦЕПТОРА }\end{array}$ & $\begin{array}{l}48,76 \\
40,69\end{array}$ & $\begin{array}{l}53,08 \\
41,26\end{array}$ & $\begin{array}{l}59,08 \\
41,36\end{array}$ & $\begin{array}{l}47,84 \\
40,39\end{array}$ \\
\hline C07A & $\begin{array}{l}\text { блокатори бета адренер- } \\
\text { гичких рецептора }\end{array}$ & $\begin{array}{l}48,76 \\
39,76 \\
\end{array}$ & $\begin{array}{l}53,08 \\
40,21 \\
\end{array}$ & $\begin{array}{l}59,08 \\
40,22 \\
\end{array}$ & $\begin{array}{l}47,84 \\
39,26 \\
\end{array}$ \\
\hline C07B & $\begin{array}{l}\text { бета адренергички } \\
\text { блокатори и тиазиди }\end{array}$ & $\begin{array}{c}0 \\
0,93 \\
\end{array}$ & $\begin{array}{c}0 \\
1,05\end{array}$ & $\begin{array}{c}0 \\
1,14\end{array}$ & $\begin{array}{c}0 \\
1,13 \\
\end{array}$ \\
\hline $\mathrm{C} 08$ & $\begin{array}{l}\text { БЛОКАТОРИ КАЛЦИ- } \\
\text { ЈУМСКИХ КАНАЛА }\end{array}$ & $\begin{array}{l}51,61 \\
50,28 \\
\end{array}$ & $\begin{array}{l}40,49 \\
52,59 \\
\end{array}$ & $\begin{array}{l}54,65 \\
54,65 \\
\end{array}$ & $\begin{array}{l}78,78 \\
55,18 \\
\end{array}$ \\
\hline $\mathrm{C} 08 \mathrm{C}$ & $\begin{array}{l}\text { селективни блокатори } \\
\text { калцијумских канала са } \\
\text { претежно васкуларним } \\
\text { деловањем }\end{array}$ & $\begin{array}{c}42,4 \\
45,46\end{array}$ & $\begin{array}{l}31,73 \\
48,05\end{array}$ & $\begin{array}{l}45,63 \\
50,41\end{array}$ & $\begin{array}{l}71,47 \\
51,26\end{array}$ \\
\hline C08D & $\begin{array}{l}\text { селективни блокатори } \\
\text { калцијумских канала са } \\
\text { директним деловањем } \\
\text { на срце } \\
\end{array}$ & $\begin{array}{l}9,21 \\
4,82\end{array}$ & $\begin{array}{l}8,76 \\
4,54\end{array}$ & $\begin{array}{l}9,02 \\
4,24\end{array}$ & $\begin{array}{l}7,31 \\
3,92\end{array}$ \\
\hline $\mathrm{C} 09$ & $\begin{array}{l}\text { ЛЕКОВИ КОЈИ ДЕЛУ- } \\
\text { ЈУ НА РЕНИН-АНГИО- } \\
\text { ТЕНЗИН СИСТЕМ }\end{array}$ & $\begin{array}{l}168,84 \\
122,34\end{array}$ & $\begin{array}{l}167,20 \\
117,91\end{array}$ & $\begin{array}{l}219,18 \\
124,64\end{array}$ & $\begin{array}{l}169,53 \\
128,72\end{array}$ \\
\hline C09A & $\begin{array}{l}\text { инхибитори ангиотен- } \\
\text { зин конвертујућег ензи- } \\
\text { ма (АЦЕ), моноком- } \\
\text { понентни }\end{array}$ & $\begin{array}{c}168,63 \\
43,40\end{array}$ & $\begin{array}{c}166,22 \\
43,92\end{array}$ & $\begin{array}{c}216,89 \\
44,75\end{array}$ & $\begin{array}{c}164,46 \\
45,02\end{array}$ \\
\hline C09B & $\begin{array}{l}\text { инхибитори АЦЕ, } \\
\text { комбинације }\end{array}$ & $\begin{array}{c}0 \\
7,11 \\
\end{array}$ & $\begin{array}{c}0 \\
6,99 \\
\end{array}$ & $\begin{array}{c}0 \\
6,91 \\
\end{array}$ & $\begin{array}{c}0 \\
6,66 \\
\end{array}$ \\
\hline $\mathrm{C} 09 \mathrm{C}$ & $\begin{array}{l}\text { антагонисти рецептора } \\
\text { ангиотензина II, моно- } \\
\text { компонентни } \\
\end{array}$ & $\begin{array}{c}0,21 \\
33,58\end{array}$ & $\begin{array}{l}0,981 \\
36,39\end{array}$ & $\begin{array}{c}2,29 \\
39,50\end{array}$ & $\begin{array}{c}5,07 \\
41,80\end{array}$ \\
\hline C09D & $\begin{array}{l}\text { антагонисти рецептора } \\
\text { ангиотензина II, } \\
\text { комбинације }\end{array}$ & $\begin{array}{c}0 \\
28,25\end{array}$ & $\begin{array}{c}0 \\
30,61\end{array}$ & $\begin{array}{c}0 \\
33,47\end{array}$ & $\begin{array}{c}0 \\
35,22\end{array}$ \\
\hline C09X & $\begin{array}{l}\text { Остали лекови који } \\
\text { делују на систем } \\
\text { ренин-ангиотензин }\end{array}$ & & & $\begin{array}{c}0 \\
0,01\end{array}$ & $\begin{array}{c}0 \\
0,02\end{array}$ \\
\hline $\mathrm{C} 10$ & $\begin{array}{l}\text { СРЕДСТВА КОЈА } \\
\text { СМАҢУЈУ ЛИПИДЕ } \\
\text { У СЕРУМУ }\end{array}$ & $\begin{array}{l}12,74 \\
76,07\end{array}$ & $\begin{array}{l}18,35 \\
86,47\end{array}$ & $\begin{array}{l}26,37 \\
97,16\end{array}$ & $\begin{array}{c}27,65 \\
104,10\end{array}$ \\
\hline $\mathrm{C} 10 \mathrm{~A}$ & $\begin{array}{l}\text { лекови који смањују } \\
\text { ниво холестерола и } \\
\text { триглицерида }\end{array}$ & $\begin{array}{l}12,74 \\
76,07\end{array}$ & $\begin{array}{c}18,347 \\
86,47\end{array}$ & $\begin{array}{l}26,37 \\
97,16\end{array}$ & $\begin{array}{c}27,65 \\
104,00\end{array}$ \\
\hline C10B & $\begin{array}{l}\text { лекови који смањују } \\
\text { липиде у серуму, } \\
\text { комбинације }\end{array}$ & $\begin{array}{l}0 \\
0\end{array}$ & $\begin{array}{l}0 \\
0\end{array}$ & $\begin{array}{l}0 \\
0\end{array}$ & $\begin{array}{c}0 \\
0,1\end{array}$ \\
\hline & ТОТАЛ & $\begin{array}{l}387,81 \\
353,09\end{array}$ & $\begin{array}{l}400,06 \\
371,67\end{array}$ & $\begin{array}{l}481,69 \\
391,87\end{array}$ & $\begin{array}{l}414,67 \\
400,61\end{array}$ \\
\hline
\end{tabular}

\section{ЗАКЉУЧАК}

Развојем е-пословања у регулативи лекова и медицинских средстава, као подсистема еуправе Републике Србије, обезбеђује се јединствено окружење за комуникацију, боље информисање о лековима и медицинским средствима, едукацију преко Интернета за здравствене раднике, као и ефикасније посло- вање у здравству и фармацији и остваривање концепта е-управе у сегменту регулативе лекова и медицинских средстава. У раду су укратко описани кораци у моделирању пословног процеса промета лекова у Србији. Прецизна дефинисаност и добра документованост RUP методологије, као и слагање са UML нотацијом доприноси да је баш ова комбинација изабрана за реализацију овог 
пројекта. Наведена методологија и дијаграми се могу применити сем у пројекту е-пословања у регулативи лекова и медицинских средстава и у другим пројектима у оквиру развоја е-управе и е-здравља РС и као образац за развој сличних система коришћењем RUP методологије и UML нотације

Имплементација оваквог система доводи до низа технолошких, функционалних и дугорочних економских предности, као што су: боље управљање документима и записима у државној управи и здравственом систему, отворен, флексибилан, конфигурисан систем и интеграција са другим информационим системима, као и могућност аутоматизације интегрисаних процеса.

\section{ЗАХВАЛНОСТ}

Захваљујем се свом ментору професору Слободану Јанковићу као и свим сарадницима из Агенције за лекове и медицинска средства Србије који су помогли израду овог рада.

\section{ЛИТЕРАТУРА}

1. Chaffey D. E-bussiness and E-commerce Management. Strategy, Implementation and Practice. 2nd ed. Harlow: FT Pretince Hall, Pearson Education, 2004.

2. Stojadinovic T. E-business in medicines and medical devices legislation [master thesis]. Belgrade: Faculty of Organizational Sciences; 2004 in Serbia.

3. Ivkovic M, Radenkovic B. Internet and contemporary business. Belgrade: Mihajlo Pupin Technical Faculty; 1998.
4. Vlada Republike Srbije. Strategija razvoja informacionog društva u Republici Srbiji do 2020. godine. Službeni glasnik Republike Srbije 2010; br. 55/05, 71/05ispravka, 101/07 i 65/08. Beograd, 2010. 41(96).

5. IBM. IBM Rational Unified Process: Best Practices for Software Development Teams. Somers, NY: IBM Corporation, 2003.

6. Kumarapeli P, De Lusignan S, Ellis T, Jones B. Using Unified Modelling Language (UML) as a process-modelling technique for clinical-research process improvement. Med Inform Internet Med. 2007;32: 51-64.

7. Kerzner H. Project Management: A Systems Approach to Planning, Scheduling, and Controlling. 8th ed. Hoboken, NJ: John Wiley \& Sons, Inc, 2003.

8. Booch G, Rumbaugh J, Jacobson I. The Unified Modeling Language User Guide. Chicago: Addison-Wesley Publishing Company, 1999.

9. WHO Collaborating Centre for Drug Statistics Methodology of Norwegian Institute of Public Health. Guidelines for ATC classification and DDD assignment 2009. Oslo, 2010.

10. Radonjic V, urednik. Promet i potrošnja lekova lekova 2006. Beograd: Agencija za lekove i medicinska sredstva Srbije i Helicon Publishing, 2007. (In Serbian).

11. Radonjic V, urednik. Promet i potrošnja lekova lekova 2007. Beograd: Agencija za lekove i medicinska sredstva Srbije i Helicon Publishing, 2008. (In Serbian).

12. Radonjic $\mathrm{V}$, urednik. Promet i potrošnja lekova lekova 2008. Beograd: Agencija za lekove i medicinska sredstva Srbije i Helicon Publishing, 2009. (In Serbian).

13. Radonjic $\mathrm{V}$, urednik. Promet i potrošnja lekova lekova 2009. Beograd: Agencija za lekove i medicinska sredstva Srbije i Helicon Publishing, 2010. (In Serbian).

14. Global Health Observatory Data Repository. Noncommunicable diseases. Available at: http://apps.who.int/ ghodata/?vid=2490\# 